\title{
A Baselining of Alternative Fuel Usage
}

\author{
Jack Fuller, ${ }^{*}$ and Robert Bessette ${ }^{2}$ \\ ${ }^{1}$ College of Business and Economics, West Virginia University, P.O. Box 6025, Morgantown, WV 26506-6025, USA \\ ${ }^{2}$ Council of Industrial Boiler Owners, 6035 Burke Centre Parkway, Suite 360, Burke, Virginia, 22015, USA
}

\begin{abstract}
Alternative fuel usage is becoming a more and more prevalent topic of discussion and important research area for those who work in the energy field and perform research on energy topics. This interest is due to the dwindling supply and increasing cost of more traditional energy supplies, as well as environmental considerations. Bio-fuels have now become an important research area as they have the potential to be able to replace some portion of the current United States dependence on traditional energy sources.

This research project performed a baselining effort on as large a sample of solid fuel boilers (utilizing the United States Environmental Protection Agency's (EPA) data) as was possible given the time and resource constraints of the project. This baselining effort in particular focused on alternative fuel usage commonly used in facilities surveyed across the United States.

It is felt that the baselining report generated as a result of this effort will provide valuable assistance to researchers as they continue to analyze the impact of alternative fuel usage (particularly the use of bio-fuels). This is a relatively new research field that will impact much of the focus on energy generation and fuel supplies for many years to come.
\end{abstract}

Keywords: Alternative fuels, boiler fuel inventory, boiler region inventory, boiler firing types.

\section{INTRODUCTION}

Alternative fuel usage is becoming a more and more prevalent topic of discussion and important research area for those who work in the energy field and perform research on energy topics. This interest is due to the dwindling supply and increasing cost of more traditional energy supplies, as well as environmental considerations. Bio-fuels have now become an important research area as they have the potential to be able to replace some portion of the current United States dependence on traditional energy sources. The United States Environmental Protection Agency (EPA) has recently published a Boiler MACT 114 Information Collection Request for development of a new rule. As a result, the EPA will be collecting a great deal of data pertaining to Industrial Commercial and Institutional (ICI) Boilers [1].

EPA will use the data collected to generate the new Boiler MACT and Commercial Industrial Solid Waste Incinerator (CISWI) Rules. Their efforts will not address the technical and energy aspects of the data. In this regard, this research project will perform a baselining effort on as many solid fuel boilers (utilizing EPA's data) as may be possible given the time and resource constraints of this project. This baselining effort will in particular focus on alternative fuel usage commonly used in facilities surveyed across the country.

It is felt that the baselining report generated as a result of this effort will provide valuable assistance to researchers as they continue to analyze the impact of alternative fuel usage

*Address correspondence to this author at the Department of Management, College of Business and Economics, West Virginia University, P.O. Box 6025, Morgantown, WV 26506-6025, USA; Tel: 304.293.7935; Fax: 304.293.8905; E-mail: jfuller@wvu.edu (particularly the use of bio-fuels) and its relationship to the Boiler MACT 114 protocol. This is a relatively new research field that will impact much of the focus on energy generation and fuel supplies for many years to come.

\section{TYPES OF BOILERS: >FROM EPA BOILER MACT 114 SURVEY}

\section{Fluidized Bed \& Gasifiers - Gasifier, Circulating, Bubbling, and Hybrid}

Fluidized bed combustion is a firing type in which the solid fuel is suspended by upward flowing jets of air during combustion, this creates a mixing of gases and solids which help promote chemical reactions and heat transfer. This technology allows for a variety of fuels to be utilized and improves pollution emissions and efficiency. The major types used in industry are circulating bed, bubbling bed, and hybrid fluidized bed [2].

\section{Suspension Fired - Pulverized Coal, Wall-Fired, and Tangential}

Pulverized Coal Combustion (PCC) is in use around the world to burn coal more efficiently. The coal is ground or pulverized into a fine powder and injected into the fire box by burner nozzles. There are multiple nozzle configurations, such as wall mounted ( 1 and 2 sided) and tangential burners in the corners of the boiler. The ash is removed from the bottom of the firing system as fly ash [3, 4].

\section{Stoker Boilers - Sloping/Stationary Grate, Traveling Grate, and Vibrating Grate}

There are many types of stoker boilers, although they all typically use a lump feed system where the fuel is burned on a grate (traveling, sloped, or vibrating). Stationary grates are normally used for small scale application and water heating, 
not steam or power production. The fuel is supplied continuously and the ash is constantly removed during operation. The disadvantage of these boilers is that emissions and pollution control can be extremely costly and inefficient $[5]$.

\section{Cyclone Furnace (Suspended Fuel)}

Cyclone Boiler or furnace technology is one in which the fuel is injected tangentially into the burner at the front end of a cylinder shaped combustion chamber. The chamber is introduced with a spiral air stream which is passed over the suspended fuel, allowing rapid and efficient combustion. This allows for a more compact size and less ash. Suitable fuels include bituminous coal, lignite coal, wood chips, tire derived fuels, and petroleum coke [6].

\section{Dutch Oven/Fuel Cell}

These two types of boilers were combined in the boiler MACT 114 data. The dutch oven boiler has a fire-box which is completely surrounded by water. In this case, the fuel typically produces a large amount of soot, and fire-tubes or water-tubes can become a maintenance nuisance. In this boiler design, the risk of overheating the steel in the firebox is minimized since it is in constant contact with the water on the opposite side. This helps reduce damage to the boiler system stemming from overheating [7].

The fuel cell is a "boiler" in which the fuel is not necessarily combusted but is combined with oxidants to produce an electro-chemical reaction to produce heat and power. These two categories compiled a small portion of the data encountered as seen in the figures below [8].

\section{TYPES OF ALTERNATIVE FUELS: FROM EPA BOILER MACT 114 SURVEY}

The heating values for the alternative fuels observed in the EPA Boiler MACT survey were compiled and classified into the seven fuel type categories: wood, agricultural, tire derived, gas byproducts, industrial sludge (solid process byproducts), used petroleum based oils, and other. The heating values for each fuel type were averaged and can be seen in the table below as well as in Fig. (1): Alternative Fuel Heating Values. The different fuels included in each category can be seen below. Most of the agricultural and wood based fuels can be classified as biomass; however they were separated as much as possible for this project.

\section{Wood Based}

These fuels include treated and untreated wood chips, bark, sawdust, hog fuel, paper, construction scrap/wood, and cardboard/container scraps.

\section{Agricultural Based}

These fuels include corn stalk, grass/hay, animal byproducts, obsolete seed, sunflower husk, black liquor, turpentine, and vegetable oil.

\section{Tire Derived Fuel}

This category references all fuels produced from tires, such as shredded and whole tires.

\section{Industrial Sludge}

Such fuels include solids from papermaking, glycerol distillate, and other solid process by-products.

\section{By-product Gases from Processes}

These refer to gases from manufacturing and chemical processes (e.g., methane and hydrogen based fuels).

\section{Waste/Trash Based}

Such fuels include suitable trash for burning (treated), waste derived liquid fuel, vent gas, and sewer gas.

\section{Used Petroleum Based Oils}

This category includes petro based fuels, such as tar, recycled motor oil, and recycled fuel residues.

\begin{tabular}{|l|c|}
\hline \multicolumn{2}{|c|}{$\begin{array}{c}\text { Average Alternative Fuel Heating Values } \\
\text { (units as listed) }\end{array}$} \\
\hline Wood/Wood Waste (BTU/lb) & $7,620.2$ \\
\hline Agricultural Based (BTU/lb) & $13,980.2$ \\
\hline Tire Derived Fuel (BTU/lb) & $15,425.0$ \\
\hline Gases byproduct/vent (BTU/Cu Ft) & 302.5 \\
\hline Industrial Sludge (BTU/lb) & $6,568.6$ \\
\hline Used Petro Based Oils (BTU/lb) & $17,993.2$ \\
\hline Other (BTU/lb) & $10,623.6$ \\
\hline
\end{tabular}

\section{CHARACTERIZATION OF ALTERNATIVE FUEL BOILERS}

Using data from the most recent EPA Boiler MACT 114 survey, alternative fuel boilers were classified according to the fuel burned as well as the region in which they are located. Though some of the boilers listed were commercial power producers, most are utilized in industries where fuels are created due to waste in manufacturing processes or byproducts of chemical processing. In this survey, there were found to be approximately 2100 boilers burning alternative fuels with a total capacity of about $300,000 \mathrm{MMBTU} / \mathrm{hr}$. Although the average size of these boilers is approximately $140 \mathrm{MMBTU} / \mathrm{hr}$, the actual boilers range in size from 1000 $\mathrm{MMBTU} / \mathrm{hr}$ down to under $10 \mathrm{MMBTU} / \mathrm{hr}$.

\section{BREAKDOWN BY FUEL}

Process byproducts make up the vast majority of alternative fuels burned, including 77 percent of the total number of boilers and 70 percent of the total capacity. Wood makes up another 21 percent of fuel and 28 percent of the total capacity. These two alternative fuels together make up approximately 98 percent of the alternative fuel burning units and capacity in the survey. Table 1, as well as Figs. $(\mathbf{2}, \mathbf{3})$, shows the distribution of boilers and their capacities by fuel.

It can be seen from these figures that process byproducts and wood are the most prevalent fuels. Wood waste is very commonly re-used in boilers for co-generation in paper and saw 


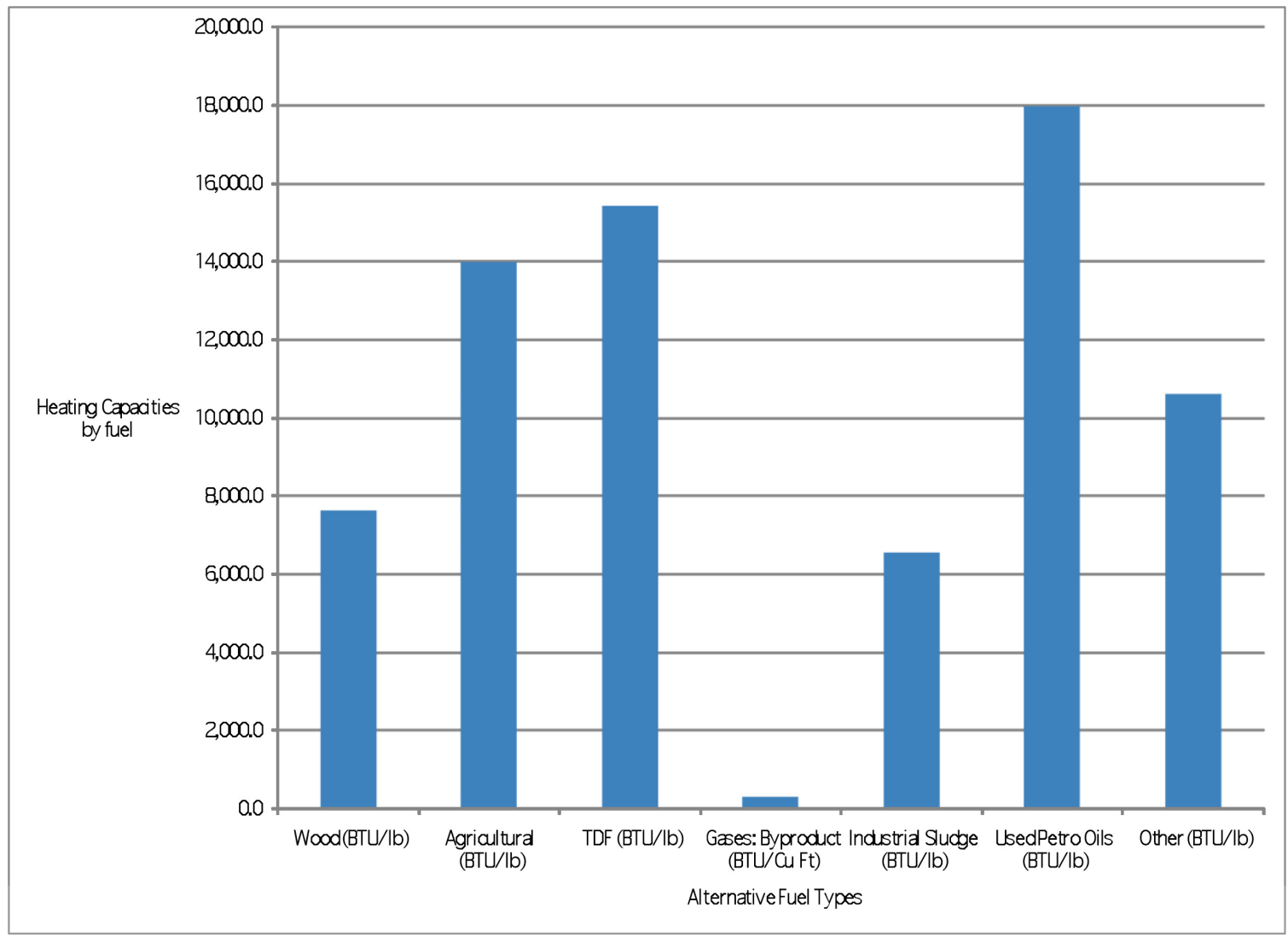

Fig. (1). Heating values of alternative fuels.

mills. It is also often resold to other companies for use in boilers as well. A vast majority of the process byproducts present in the survey were refinery gases used in various oil refineries throughout the country. These gases, which are left over after oil refinement, provide an alternative fuel for use in boilers in these facilities for co-generation or power production.

Table 1. Boiler Fuel Inventory

\begin{tabular}{|c|c|c|c|}
\hline Fuel & $\begin{array}{c}\text { Number } \\
\text { of Boilers }\end{array}$ & $\begin{array}{c}\text { Boiler Capacity } \\
\text { (MMBTU/hr) }\end{array}$ & $\begin{array}{c}\text { Average Size } \\
\text { (MMBTU/hr) }\end{array}$ \\
\hline \hline Agricultural & 2 & 75 & 38 \\
\hline Waste & 1 & 179 & 179 \\
\hline Process Byproducts & 1,603 & 207,102 & 129 \\
\hline Wood & 452 & 84,830 & 188 \\
\hline Landfill/Sewage Gas & 14 & 1,098 & 78 \\
\hline Other & 14 & 4,581 & 327 \\
\hline Total & $\mathbf{2 , 0 8 6}$ & $\mathbf{2 9 7 , 8 6 5}$ & $\mathbf{1 4 3}$ \\
\hline
\end{tabular}

\section{BREAKDOWN BY REGION}

From Table 2, it can be seen that approximately a third of the boilers and total capacity included in the survey are located in the West South Central. It houses substantially more boilers than any other region. This distribution once again is due to the prevalence of oil refineries in the region, which account for a large percentage of the alternative fuel boilers. The South Atlantic, East North Central, East South Central, and Pacific regions show similar numbers of boilers, as well as boiler capacity and average size. Although the New England region houses the least number of boilers and the lowest capacity, it has the largest average boiler size of any region with an average of $407 \mathrm{MMBTU} / \mathrm{hr}$. Conversely, the Mountain region has the smallest average boiler size at only $60 \mathrm{MMBTU} / \mathrm{hr}$ (The information in Table 2 is depicted graphically in Figs. $(4,5)$ ).

\section{COMPARISON OF REGION AND FUEL TYPE}

As shown in Fig. (6), the number of boilers using wood as fuel only exceeds the number of boilers using process byproducts in the New England and South Atlantic Regions. In every other region, the number of boilers using process byproducts greatly exceeds that of any other fuel type. In Fig. (7), the capacity of the boilers generally follows a similar pattern. However, in the East South Central and West North Central regions, the total capacity of boilers using wood are very close to the total capacity of boilers using process byproducts.

\section{Breakdown by Firing Type}

The suspension fired and stoker firing types make up approximately 57 percent of the boilers surveyed (see Table 3 and Fig. (8)). Those listed as other made up an additional 40 percent of the data. This is due in part to the prevalence of suspension fired and stoker boilers in the burning of coal. These boilers are more common and can be converted to burn alternative fuels as well. Fluidized bed, cyclone furnace, and fuel cell boilers are newer and less common technologies that are beginning to gain popularity for use in larger scale boiler and alternative fuel applications. 


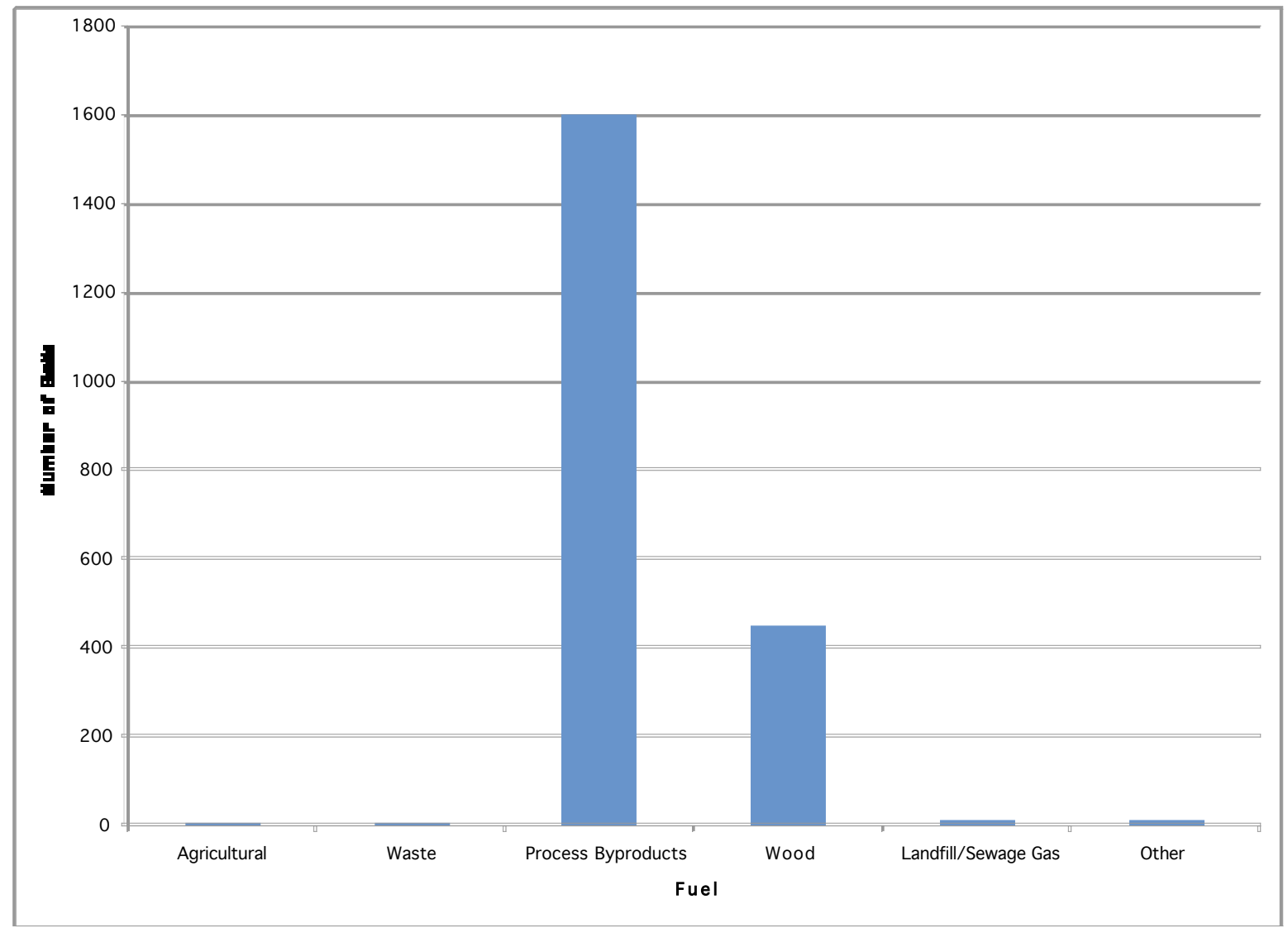

Fig. (2). Boilers by fuel type.

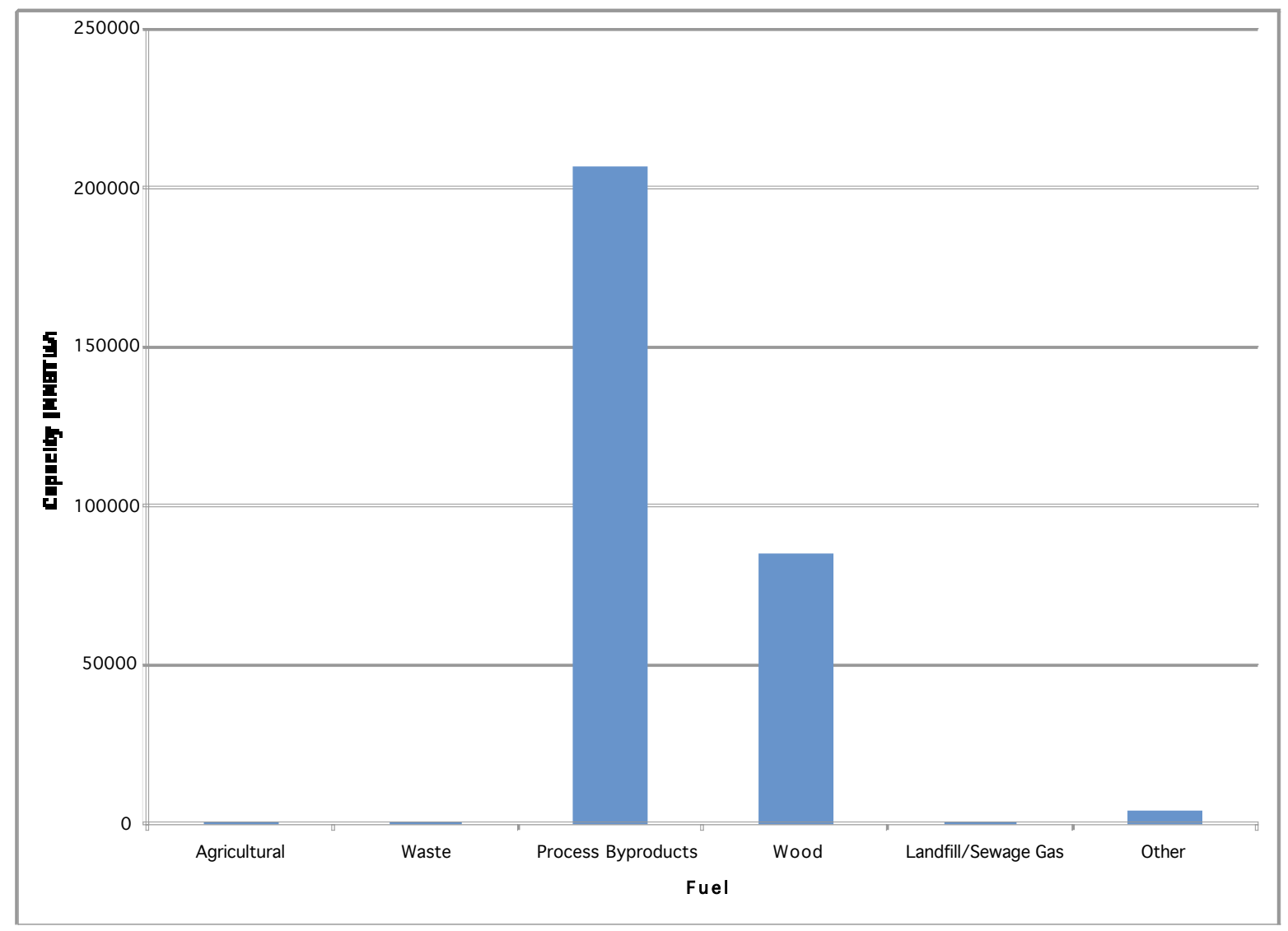

Fig. (3). Capacity by fuel type. 
Table 2. Boiler Region Inventory

\begin{tabular}{|c|c|c|c|}
\hline Region & $\begin{array}{c}\text { Number } \\
\text { of Boilers }\end{array}$ & $\begin{array}{c}\text { Boiler Capacity } \\
\text { (MMBTU/hr) }\end{array}$ & $\begin{array}{c}\text { Average Size } \\
\text { (MMBTU/hr) }\end{array}$ \\
\hline \hline NE & 10 & 4072 & 407 \\
\hline MA & 150 & 22958 & 153 \\
\hline SA & 220 & 41798 & 159 \\
\hline ENC & 278 & 44337 & 103 \\
\hline WNC & 106 & 10875 & 133 \\
\hline ESC & 256 & 33940 & 142 \\
\hline WSC & 696 & 98864 & 60 \\
\hline MTN & 118 & 7098 & 135 \\
\hline PAC & 252 & 33922 & $\mathbf{1 4 3}$ \\
\hline Total & $\mathbf{2 0 8 6}$ & $\mathbf{2 9 7 8 6 5}$ & \\
\hline
\end{tabular}

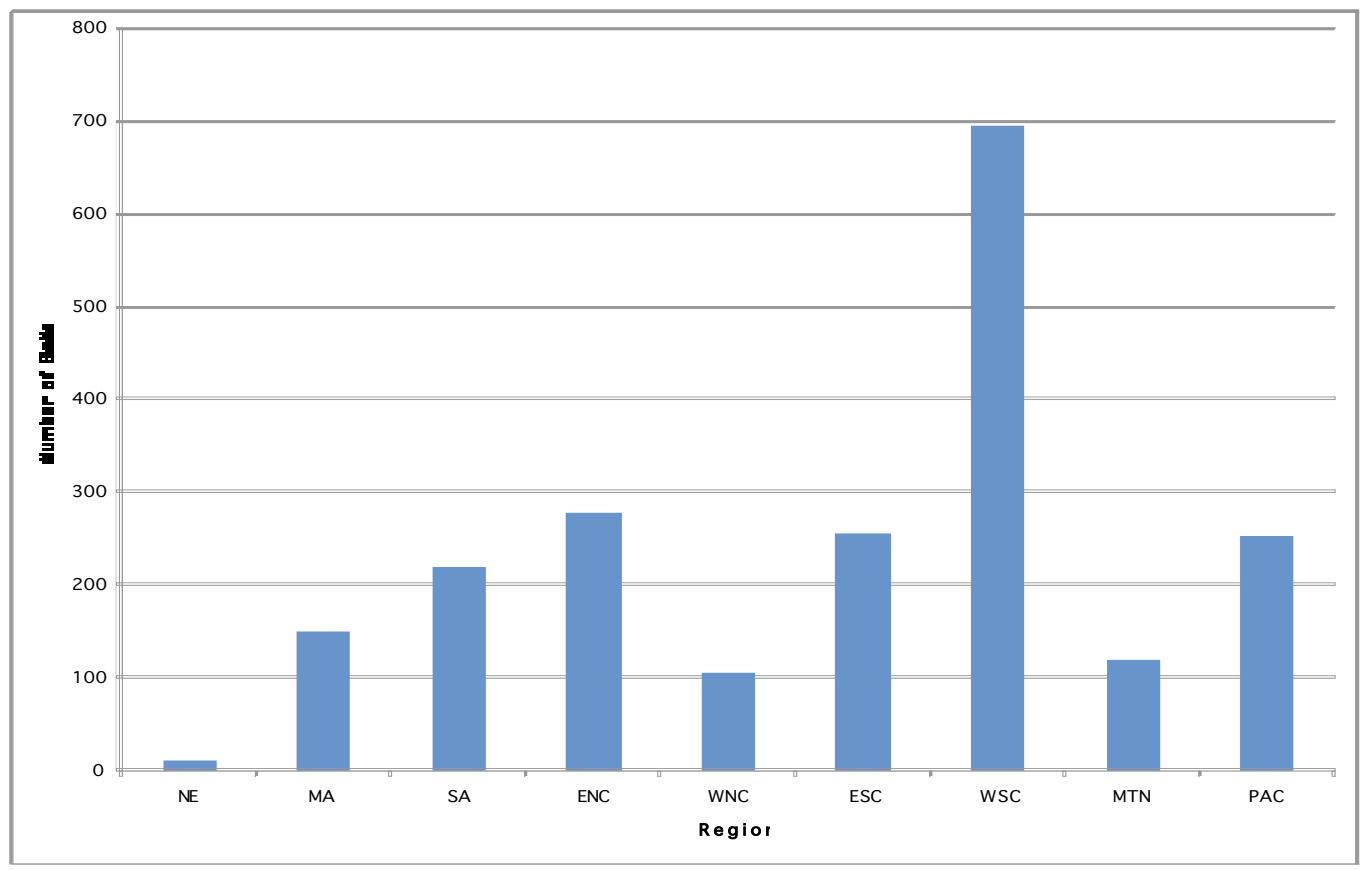

Fig. (4). Boilers by region.

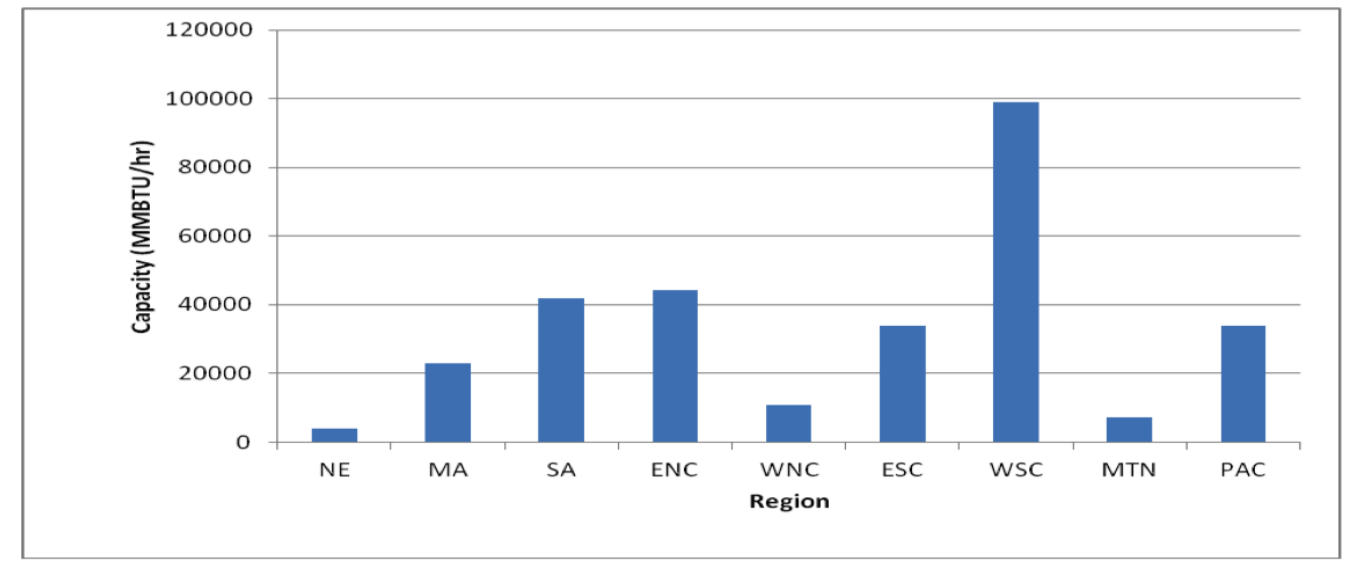

Fig. (5). Capacity by region. 


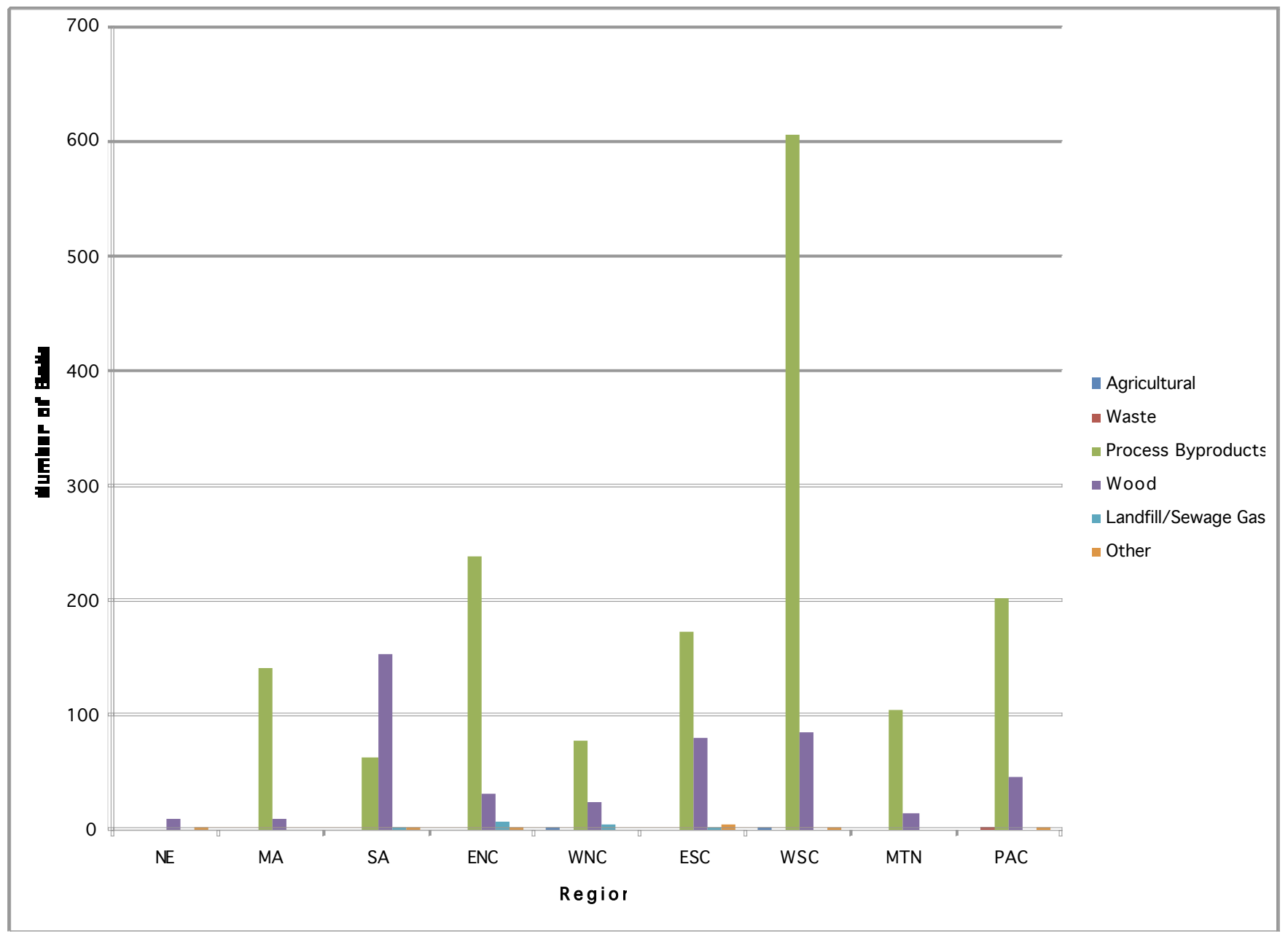

Fig. (6). Number of boilers by fuel type and region.

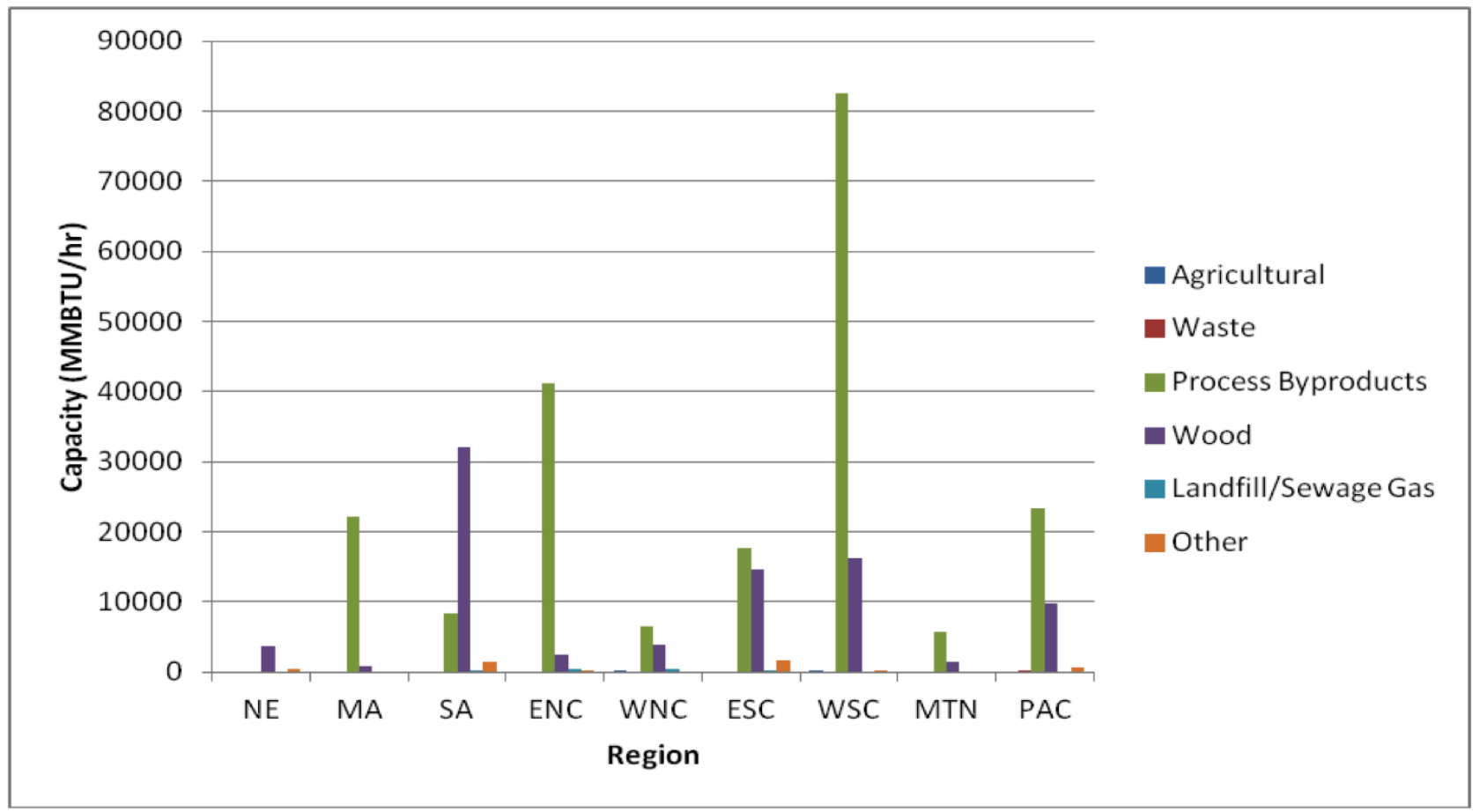

Fig. (7). Capacity by fuel type and region. 


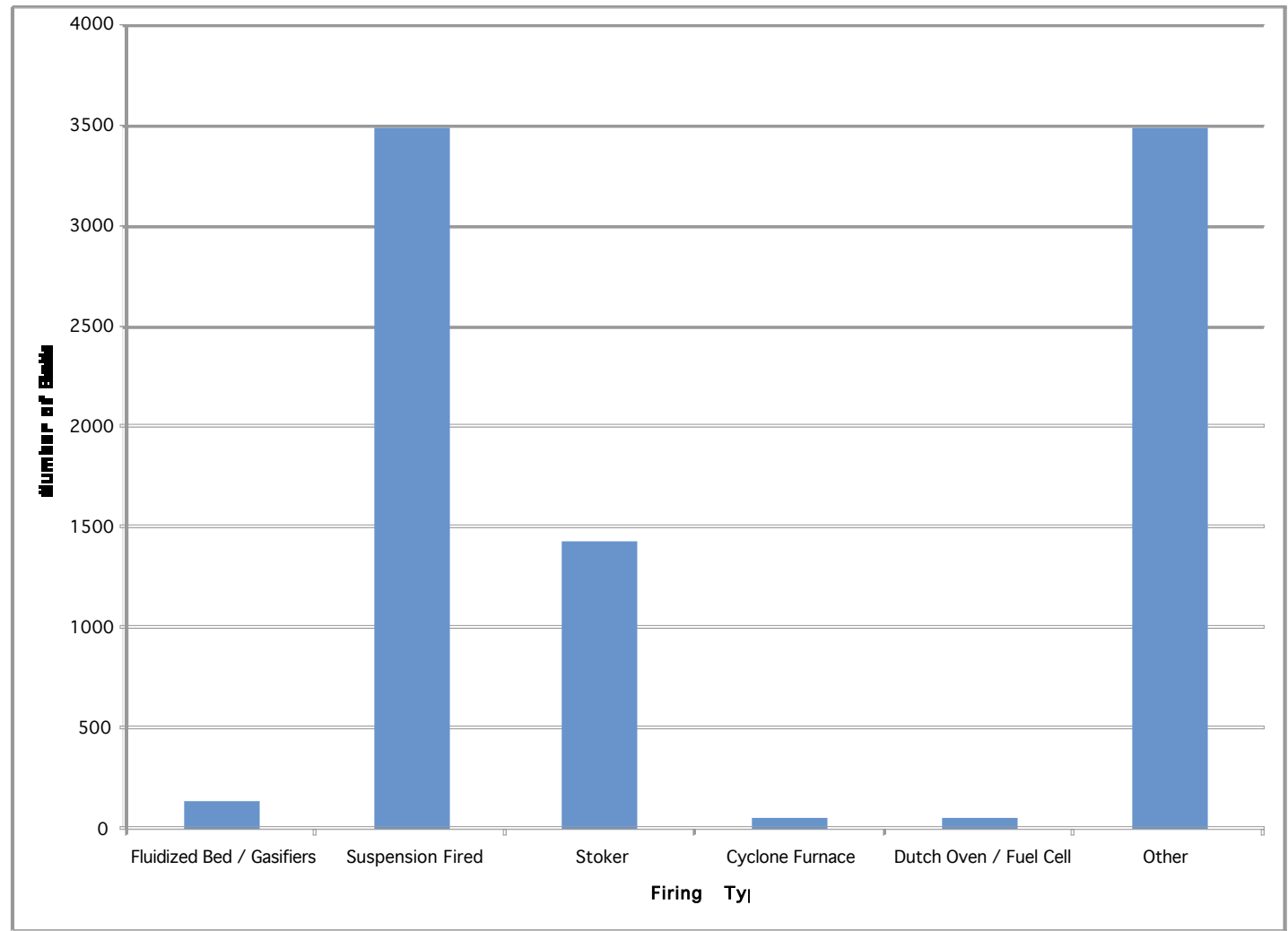

Fig. (8). Boilers by firing type.

Table 3. Boilers by Firing Type

\begin{tabular}{|c|c|}
\hline Firing Type & Number of Boilers \\
\hline \hline Fluidized Bed/Gasifiers & 135 \\
\hline Suspension Fired & 3,489 \\
\hline Stoker & 1,429 \\
\hline Cyclone Furnace & 47 \\
\hline Dutch Oven/Fuel Cell & 58 \\
\hline Other & 3,489 \\
\hline Total & $\mathbf{8 , 6 4 7}$ \\
\hline
\end{tabular}

\section{CONCLUSIONS}

With the popularity of alternative fuels increasing yearly, it is necessary to evaluate and base-line the current alternative fuel usage in industry. By baselining the most current MACT data, it is possible to see the trends in alternative fuel usage across the country and to predict future trends for further alternative fuel usage. As seen above, process byproducts and wood based fuels are the most common alternative fuels being used by facilities in the MACT data. Among the fuels used, petroleum products and tire derived fuels yield the most energy per pound, while wood and agricultural products are the only truly renewable resources among the alternative fuels observed. Also, the West South Central region has the highest number of boilers and the highest capacity. Finally, the majority of alternative fuel boilers in use are suspension fired, with a large portion being included in the "other" category. It cannot be determined from the data what is included in the "other" category. From this data, further research can determine the types and amounts of fuel available, as well as the viability of future alternative fuel boilers in each region.

\section{ACKNOWLEDGEMENT}

The authors acknowledge financial support from the United States Department of Energy in developing this research. All conclusions are those of the authors and should not be attributed to the sponsoring agency.

$$
\begin{array}{ll}
\text { ABBREVIATIONS } \\
\mathrm{BTU} \quad=\text { British Thermal Unit } \\
\mathrm{EPA} \quad=\text { Environmental Protection Agency } \\
\mathrm{ENC} \quad=\text { East North Central Region } \\
\mathrm{ESC} \quad=\text { East South Central Region } \\
\mathrm{MA} \quad=\text { Mid Atlantic Region } \\
\text { MACT } & =\text { Maximum Achievable Control Technology } \\
\mathrm{MMBTU} & =\text { Million British Thermal Units } \\
\mathrm{MTN} & =\text { Mountain Region } \\
\mathrm{NE} & =\text { New England Region } \\
\mathrm{PAC} & =\text { Pacific Region } \\
\mathrm{SA} & =\text { South Atlantic Region } \\
\mathrm{WNC} & =\text { West North Central Region } \\
\mathrm{WSC} & =\text { West South Central Region }
\end{array}
$$


APPENDIX A - MAP OF U.S. CENSUS REGIONS

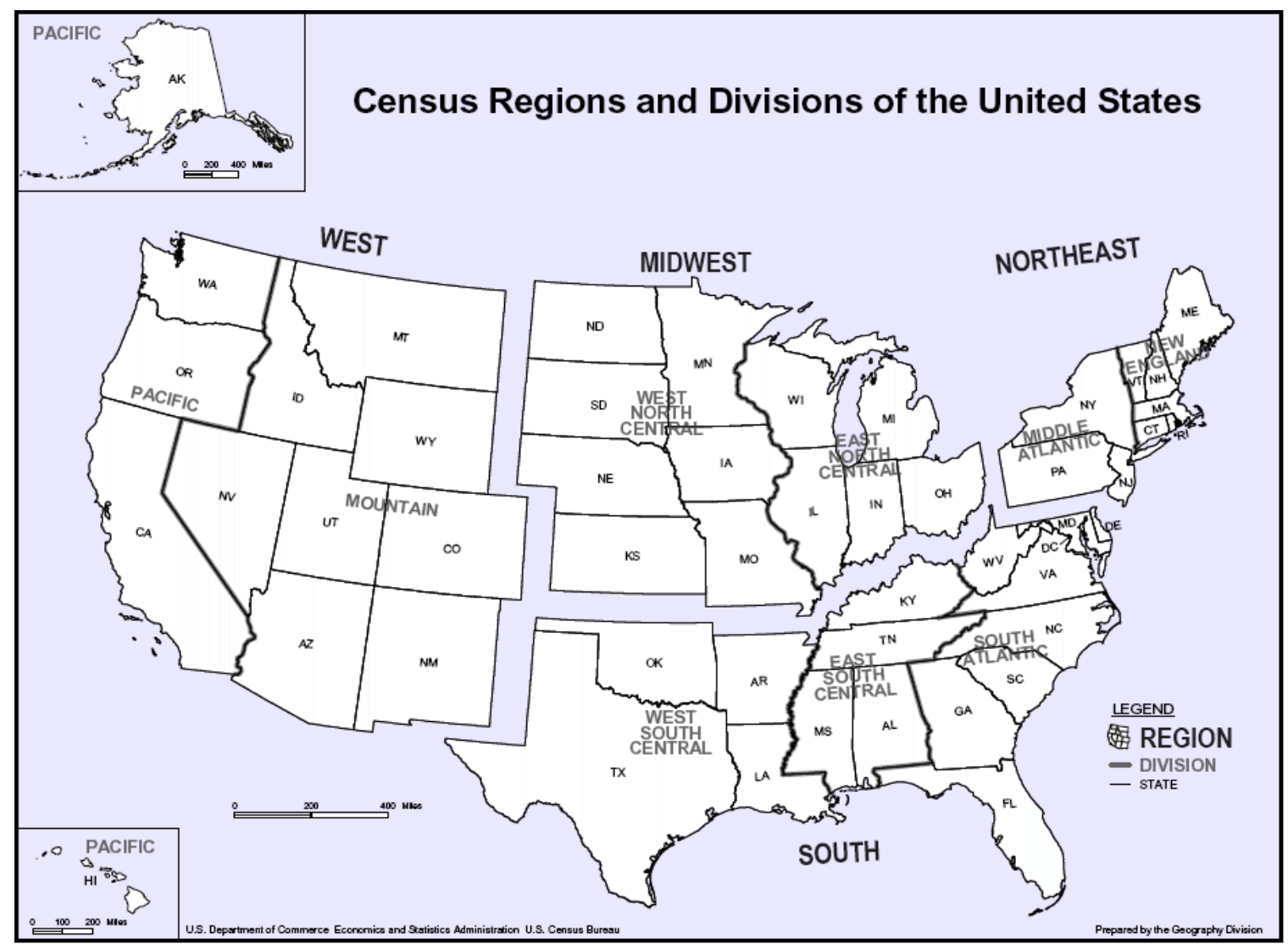

\section{REFERENCES}

[1] A Basic Overview of Fuel Cell Technology, 2008. Available from: http://americanhistory.si.edu/fuelcells/basics.htm

[2] Basu P. Combustion and Gasification in Fluidized Beds. Boca Raton, FL: Taylor \& Francis Group 2006.

[3] IEA Clean Coal Centre - Pulverized Coal Combustion, 18 April 2010. Available from: http://www.coal.org.uk/site/coalonline/con tent/Viewer/81996/6798/6798_1.html/Coal-combustion-technology IEA Clean Coal Centre - Cyclone Furnace, 18 April 2010. Available from: http://www.coal.org.uk/site/coalonline/content/Vi ewer/81996/6798/6798_1.html/Coal-combustion-technology
IEA Clean Coal Centre - Stoker Furnace, 18 April 2010. Available from: http://www.coal.org.uk/site/coalonline/content/Viewer/8199 6/6798/6798 1.html/Coal-combustion-technology

[6] Maine Wood Furnaces - The Dutch Oven Design, 2005/2008. Available from: http://www.mainewoodfurnaces.com/DO.shtml\#dutch

[7] Preliminary Database for Boilers, Process Heaters, Incinerators and Other Combustion Units. Available from: http://survey.erg.com/ss/ data/CEM/ MjrBlrandPH_v1_032009.zip

[8] Pulverized Coal_Combustion, 18 April 2010. Available from: http:// www.britannica.com/EBchecked/topic/483333/pulverized-coal-combustion

(C) Fuller and Bessette; Licensee Bentham Open.

This is an open access article licensed under the terms of the Creative Commons Attribution Non-Commercial License (http://creativecommons.org/licenses/by$\mathrm{nc} / 3.0 /$ ) which permits unrestricted, non-commercial use, distribution and reproduction in any medium, provided the work is properly cited. 